\title{
Characterization of Dairy Waste Whey and Its' Utilization for the Production of Ethanol
}

\author{
Wubshet Alemu Woldie \\ Chemical Engineering Department, College of Engineering, Debra Berhan University, Debra Berhan, Ethiopia \\ Email address: \\ alemwub419@gmail.com \\ To cite this article: \\ Wubshet Alemu Woldie. Characterization of Dairy Waste Whey and Its' Utilization for the Production of Ethanol. American Journal of \\ Chemical Engineering. Vol. 9, No. 5, 2021, pp. 112-118. doi: 10.11648/j.ajche.20210905.11
}

Received: August 24, 2021; Accepted: September 8, 2021; Published: September 23, 2021

\begin{abstract}
The objective of this study was characterization of dairy waste whey and its' utilization for the production of ethanol. Whey is a byproduct and not considered as a resource in many milk processing factories. Usually, it is discharged to rivers and surface water. The physiochemical characteristics of whey was determined by Lactoscan Milk Analyzer, Refractometer and Titration Methods. Dairy whey consisted of biological oxygen demand and chemical oxygen demand. It represents largely disaccharide sugar content which is known as lactose $(0.36-0.48) \mathrm{g} / \mathrm{mL}$ and it could highly pollute the environment or water bodies. However, this whey waste was changed into ethanol by yeast strain, kluyveromyces delphensis. The experimental design was studied with central composite design to investigate the effects of significant factors including initial lactose concentration, yeast cell concentration, temperature and $\mathrm{pH}$ value on fermentation process. In the present work, the best operating conditions were found at $6.15 \mathrm{~g} / \mathrm{L}$ (initial lactose conc.), $10 \mathrm{~g} / \mathrm{L}$ (yeast cell conc.), $27^{\circ} \mathrm{C}$ (temperature) and 5.5 $\mathrm{pH}$ value respectively. The maximum ethanol yield obtained from cheese whey was $40.4 \%$ (2.5g/L). Functionally, ethanol was determined by Fourier Transmission Infrared with the help of Infrared correlation charts and moreover, its characteristic was investigated. As a result, cheese whey is a good resource for a production of ethanol.
\end{abstract}

Keywords: Characterizations, Cheese Whey, Ethanol, Fermentation, Kluyveromyces, Substrate, Yeast

\section{Introduction}

Milk is the natural food designed for mammals and it provides energy from the carbohydrate present in the form of lactose. Milk also provides other important through evolution. Based on its' benefits, there are some factories processing milk into desired products and generates by products such as whey. Currently, there are over 22 medium- and large-scale dairy processing companies in Ethiopia with nine of them operating in Addis Ababa and the rest in other major regional cities [8].

Whey is an abundant waste stream generated during cheese production [17]. Continuous land disposal of cheese whey can endanger the physical and chemical structure of the soil, decrease the crop yield, and lead to serious water pollution problems $[10,14]$. Whey is the watery and thin liquid, which is received during cheese making by coagulating and separating casein proteins from milk [22]. The normal whey samples either sweet or acid were concentrated using vacuum scraper concentrator [3]. The disposal of whey is a worldwide problem in dairy industry. Cheese whey is produced in huge amounts and is a significant environmental problem due to the high levels of organic matter content. Cheese whey represents a biochemical oxygen demand and a chemical oxygen demand. Lactose is largely responsible for the high BOD and COD [11]. Large quantities of whey are produced as a byproduct during the manufacture of cheese and casein; which must be processed in an environmentally acceptable form before disposal as they can quickly deplete oxygen level in natural water systems because of its high chemical oxygen demand [7]. Cheese whey is utilized for different purposes [4].

Although several possibilities of cheese whey utilization have been explored, a major portion of the world cheese whey production is discarded as effluent. Its' disposal as waste poses serious pollution problems for the surrounding environment [15]. Regarding the socio-economic and environmental issues, ethanol production contributes to mitigate the price rise of fossil fuels and energy security as well as it reduces greenhouse gases effects on environment [9]. 
Now a day, bioprocess plays a major role in biomass transformation for the manifold generation of energy and its recovery [6]. It should be added that the whey has already been tested to be exploited as raw material for the fermentation and production of various metabolites, such as citric acid, ethanol, and the production of animal feed [15]. Utilization of cheese whey as a fermentation substrate to produce ethanol is an effort to supply renewable energy [1]. Ethanol is a high-octane fuel which is used primarily as a gasoline additive and extender [19, 18]. Bioethanol, derived from starch crops like sugarcane, sugar beets, corn, wheat, cheese whey and sorghum is utilized blended with petroleum based gasoline, and biodiesel, derived from oil crops like rapeseed, palm oil, Jatropha, sunflower, and soy is utilized blended with petroleum based diesel [13]. Ethanol is a source of energy and renewable energy sources with no emission of greenhouse gases. Domestic production and use of ethanol for fuel can decrease dependence on foreign oil [24]. Therefore, using ethanol for automobiles can significantly reduce non- renewable fuels (oil, coal) use and exhaust greenhouse gases emission. Production of ethanol from sugar containing materials is technically feasible as well as its use is environmentally friendly. Ethanol production from cellulosic materials is highly expensive because it needs separation technique to hydrolysis cellulosic materials to small sugar molecules. However, ethanol production from dairy cheese whey is inexpensive since the process no requirement for further separation techniques. Additionally, cheese whey is highly available for ethanol production [20].

Development of novel alternative technologies that require minimal preprocessing would not only improve overall economics for the ethanol industry, but would also create a new value-added market for this surplus dairy waste stream and reduce the environmental burden of whey permeate disposal [16]. It is known that the fermentation process performance is affected by operational conditions such as temperature, stirring rate, initial inoculums and substrate concentrations, dissolved oxygen, among others. The growth and metabolic activities of micro-organisms are profoundly affected by the temperature at which they grow [5]. A suitable control of these variables is great importance for a respectable process performance and procurement of highquality products. Some of the ethanol is further purified to make an anhydrous product [12]. Optimizations of ethanol yield from Cheese Whey through Response surface methodology with central composite design provide proper design for operating condition [2].

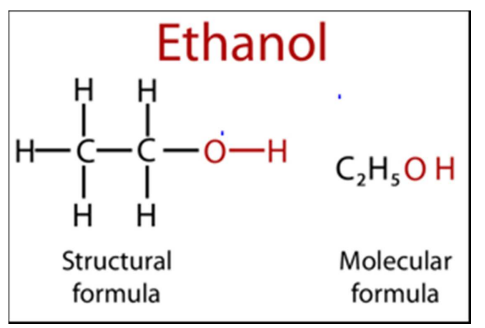

Figure 1. Ethanol Structural and Molecular Formula.

\section{Methodologies}

\subsection{Materials and Chemicals}

\subsubsection{Apparatus}

Storage tank was used in order to store dairy cheese whey from milk processing unit operations. The temperature of this whey was decreased at room temperature and solid matters were filtered using centrifuge. Lactose contents of whey were concentrated by using vacuum evaporator to obtain high yield of ethanol. Also microorganism (yeast) used for fermentation was sterilized with autoclave and incubators. Erlenmeyer flasks were used to hydrolyze lactose to ethanol and the ethanol product was separated by distillation column. Mass concentration of sugar was measured by density meter and the brix or total solid soluble of cheese whey was measured by both Density Meter and Refractometer (Laboratory Density DMA 4100M Anton Paar GmbH, Anton - Paar str.20, A 8054 Graz, AUSTRIA - EUROPE). Water bath and oil bath were also used as energy source. The spectrophotometer (Spectro UV-VIS Double Beam PC 8 Scanning Auto Cell UVD - 3200, Labomed, INC) was used to measure the absorbance to know the concentration. Additionally, the cell density and viability were determined by Microscope (Biological Microscope MB100-9090, Acculab-USA). Fourier Transmission Infrared (Perkin Elmer spectrum 65 FT-IR Spectrophotometer) was used to determine the functional group of ethanol produced from cheese whey.

\subsubsection{Chemicals}

Agar was used to count colony forming unit (CFU) of Kluyveromyces delphensis yeast and to support growth on solid with plate. However, nutrient broth was used to increase and grow yeast in liquid or suspension form. Some nutrient broth, dextrose, ammonium sulfate, peptone, $\mathrm{KH}_{2} \mathrm{PO}_{4}$ and $\mathrm{MgSO}_{4} 7 \mathrm{H}_{2} \mathrm{O}$ (purity 99\%) were added as supplement to prepare culture media. Sulphuric acid was used for hydrolysis of the cheese whey. $\mathrm{NaOH}$ and $\mathrm{H}_{2} \mathrm{SO}_{4}$ (purity $97 \%$ ) were also used to adjust the $\mathrm{pH}$ of whey as well as Benedict's solution and lactose standard solutions were used to detect sugar concentration. Methylene blue solution also used as straining technique to observe both viable and dead cell with the help of Microscope.

\subsubsection{Substrate}

Cheese whey was collected from dairy factory shola milk processing and characterized by lactoscan milk analyzer in this factory. In all dairy milk processing industries and private enterprises, the cheese whey was collected and stored in storage tank. The stored cheese whey was transported to ethanol production sites. Cheese whey served as substrate and helped microorganism to rely on it. Dairy cheese whey was a byproduct that containing lactose $(0.36-0.48 \mathrm{~g} / \mathrm{mL})$ and was used as fermentation media to support microorganism growth during fermentation. Sugar was added to fermentation in order to obtain good yield of ethanol or to facilitate fermentation.

\subsubsection{Yeast}

The yeast strain (kluyveromyces delphensis) used in this study was gifted from Ethiopian Biodiversity Institute in Addis 
Ababa, capital city of the country. The major carbohydrate in whey was lactose and it was a disaccharide sugar containing glucose and galactose. The kluyveromyces delphensis had ability to ferment lactose into ethanol as well as its activity facilitated lactose in the cheese whey to be hydrolyzed into glucose and galactose that finally fermented into ethanol.

\subsection{Preparations and Pretreatments of Cheese Whey}

Cheese whey was collected from dairy factory shola milk processing plant located in Addis Ababa capital city of Ethiopia and its components were characterized by analytical methods in laboratory before and after filtration. The main environmental quality determining parameters that had been characterized were chemical oxygen demand (COD), biological oxygen demand (BOD), total solids (TS), $\mathrm{pH}$ and the components of cheese whey that had been determined by milk analyzer (Lactoscan) at shola milk processing factory were lactose, protein, minerals, fats, and lactic acid. These compositions were determined in laboratory through analytical instruments and methods as following;

\subsubsection{Filtration of Cheese Whey}

The cheese whey collected from dairy factory was filtered using vacuum pump and filter paper to remove suspended solids and residual lipids.

\subsubsection{Deproteinization of Cheese Whey}

Hard cheese whey was normally deproteinized by heating the whey at $90^{\circ} \mathrm{C}$ for fifteen minutes to denature the protein. The protein was removed in forms of flocculants during the sterilization of cheese whey at $90^{\circ} \mathrm{C}$ with Autoclave. The protein coagulated was removed by filtration methods.

\subsubsection{Hydrolysis of Cheese Whey}

Lactose hydrolysis was catalyzed enzymatically by heating in the presence of strong mineral acids, Sulphuric acid. For acid hydrolysis, it was necessary to lower the $\mathrm{pH}$ of the lactose solution to 2.3 and heated to approximately $140^{\circ} \mathrm{C}$ for fifteen minutes using Autoclave. This hydrolysis of the lactose made lactose sweetness and prevented lactose crystallization in concentrated whey syrups. Also, solubility of lactose was increased and viscosity of whey was decreased by Sulphuric acid hydrolysis.

\subsubsection{Concentrating of Cheese Whey}

Cheese whey was concentrated by rotary vacuum evaporator at $105^{\circ} \mathrm{C}$. The initial concentration of lactose in whey was $4.5 \mathrm{~g} / \mathrm{L}$. The first sample, $500 \mathrm{ml}$ of cheese whey containing lactose was concentrated $105^{\circ} \mathrm{C}$ for 3 hours. The second $500 \mathrm{ml}$ of cheese whey sample was also concentrated at $105^{\circ} \mathrm{C}$ for 5 hours.

\subsection{Inoculums Preparation}

There were different types of yeast used to ferment carbohydrates based on their sugar type. However, lactose was metabolized by Kluyveromyces delphensis yeast strain and it was maintained in $64 \mathrm{~g} / \mathrm{l}$ agar. $500 \mathrm{ml}$ Erlenmeyer flask was washed and sterilized with autoclave at $121^{\circ} \mathrm{C}$ for 15 minutes. Then, $200 \mathrm{ml}$ distilled water was poured into $500 \mathrm{ml}$ empty Erlenmeyer flasks. Reagents (4gm of Nutrient broth, $3 \mathrm{gm}$ of Peptone and $2 \mathrm{gm}$ of Yeast extract) were measured and added into Erlenmeyer flask contained distilled water. The solution was shaken on heater to mix the reagents with distilled water and thus, it was sterilized at $121^{\circ} \mathrm{C}$ for 15 minutes. The sterilized broth was cooled and the kluyveromyces delphensis yeast strain was transferred into Erlenmeyer flask contained broth under UV-visible light (cleaned Cabinet by Alcohol) to avoid contamination. Then, it was taken into incubator and maintained for three days in shaker at temperatures of $26^{\circ} \mathrm{C}$ with velocity of $200 \mathrm{rpm}$ (for each flask). At complete growth, the kluyveromyces delphensis yeast strain cultured was preserved with microorganism conserver at $4^{\circ} \mathrm{C}$.

\subsubsection{Yeast Cell Density}

The cell density was determined by counting cells colony forming units with microscope after the cell serial dilution and growth on plate were obtained. The colony forming units was counted by microscope for each broth (3 flasks with different concentration).

\subsubsection{Yeast Cell Viability}

The kluyveromyces delphensis yeast strain health was determined by microscope with methylene blue standard solution. Both the live cell and dead cell were isolated.

\subsection{Ethanol Fermentation from Whey}

The whey from dairy plant was cooled and filtered to remove solid matters by centrifuge. $1000 \mathrm{~mL}$ Erlenmeyer flasks were washed and dried. $500 \mathrm{~mL}$ of cheese whey substrate was poured into $1000 \mathrm{~mL}$ Erlenmeyer flasks and supplements $(1.5 \mathrm{gm}$ of Nutrient broth, $1.5 \mathrm{gm}$ of peptone, $1.5 \mathrm{gm}$ of $\mathrm{NH}_{4} \mathrm{Cl}, 0.5 \mathrm{gm}$ of $\mathrm{MgSO}_{4} .7 \mathrm{H}_{2} \mathrm{O}$ and $1 \mathrm{gm}$ of $\mathrm{KH}_{2} \mathrm{PO}_{4}$ ) were added into flasks contained cheese whey substrate. The substrate mixture was preheated to mix properly and its $\mathrm{pH}$ was adjusted before sterilization. Then, it was sterilized at $121^{\circ} \mathrm{C}$ temperature for fifteen minutes with Autoclave and the sterilized substrate was cooled and maintained under UV- light to avoid bacterial contamination. Inoculated kluyveromyces delphensis yeast strain was added into flask contained sterilized substrate under UV- light. Finally, it was taken into incubator for three days at different temperatures $\left(27,31\right.$ and $\left.35^{\circ} \mathrm{C}\right)$ and $200 \mathrm{rpm}$ respectively. The initial lactose concentrations, yeast cell concentrations and ethanol concentrations were measured at 10 hours' difference.

\subsection{Distillation}

The distillation column setup was fixed. The beer from fermentation was added into flask and tied with condenser. The oil bath temperature was set to $78^{\circ} \mathrm{C}$ and condenser temperature was set to $0^{\circ} \mathrm{C}$. The distillate was collected for one day and measured.

\subsection{Functional Groups of Ethanol by FT- IR}

The functional groups of cheese whey ethanol were 
determined by using prinks Elmer spectrum 65 FT-IR with the help of IR correlation charts in Addis Ababa University, 4kilo chemistry department. The IR spectrum was reported by $\%$ transmittance. The wave number region for the analysis was in the mid-infrared range.

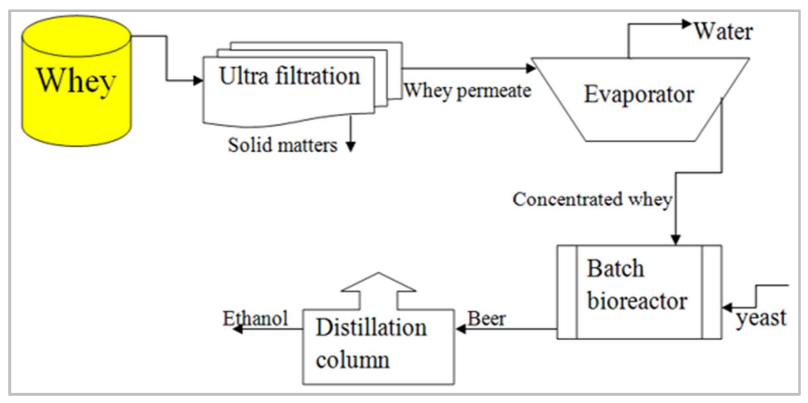

Figure 2. Ethanol Production Process Flow Diagram.

\section{Results and Discussions}

\subsection{Evaluation of Cheese Whey Characterization}

The determined BOD is $230 \mathrm{mg} / \mathrm{mL}$ and a value of cheese whey indicates high contents of organic loading and thereby, cheese whey discharged to the environment can cause environmental problem. Chemical oxygen demand (COD) was also determined by titration with ferrous ammonium sulfate reagents in laboratory and the obtained values of chemical oxygen demand $(70 \mathrm{mg} / \mathrm{mL})$ shows cheese whey discharged to environment before treatment has capability to pollute environment.

\subsubsection{Fat, Lactose \&Protein Content Determination}

Fat component of the cheese whey was determined by analytical instruments of Milkoscan or Lactoscan in shola milk processing laboratory and the fat measured was $0.026 \mathrm{~g}$ in one milliliter of cheese whey. The sugar content of cheese whey was the main component of the whey that could be fermented into ethanol and it was determined by Lactoscan analytically in the laboratory at the factory. The cheese whey had high value of lactose which gave a good yield of ethanol by fermented with kluyveromyces delphensis yeast strain as well as the lactose determined was $0.36-0.48 \mathrm{gm} / \mathrm{mL}$ of cheese whey. The total protein components of cheese whey also determined in laboratory at shola milk processing diary factory with milk analyzer of Lactoscan and the measured value was $0.024 \mathrm{~g}$ in one milliliter of hard cheese whey.

\subsubsection{Mineral Salts, Total Solid \& Ash Determination}

Lactoscan analytical instrument was milk analyzer that could determine the salt components of cheese whey and the determined value of mineral salt was $0.005 \mathrm{~g}$ in one milliliter of whey and it was less content of whey. Milk analyzer was also had capacity to determine the solid matters in whey and the determined value was $0.0065 \mathrm{~g}$ in the milliliter of whey and it could be removed by centrifuge to avoid disturbance during fermentation. The calculated ash content is 0.101 .

\subsubsection{Density \& pH Determination}

The density of cheese whey also determined by Lactoscan at whey sample temperature $19.97^{\circ} \mathrm{C}$ (with accuracy of $+1 \%$ for the range of $\left(1^{\circ} \mathrm{C}\right.$ to $\left.\left.40^{\circ} \mathrm{C}\right)\right)$ and it was $1001.9 \mathrm{Kg} / \mathrm{m} 3$ (with accuracy of $+0.3 \mathrm{Kg} / \mathrm{m} 3$ ). The $\mathrm{pH}$ of cheese way was also determined by this instrument and was $4.24 \mathrm{pH}$ value. It was shown acidic properties.

\subsection{Determination of Sugar for Cheese Whey}

The concentration of total reducing sugar in the hydrolyzed whey was obtained from the calibration plot in the above and expressed in $\mathrm{gm} / \mathrm{ml}$ in table above. The maximum reducing sugar was $7.8 \mathrm{~g} / \mathrm{L}$ determined by calibration curve.

\subsection{Studied Cell Density and Viability}

Dry cell mass concentration was estimated by measuring the optical density of the sample at $600 \mathrm{~nm}$ in spectrophotometer (Spectro UV-VIS Double Beam PC 8 Scanning Auto Cell UVD - 3200, Labomed, INC). The cell health was determined by methylene blue staining technique $0.2 \mathrm{~mL}$ sterile solution of methylene blue $(3.3 \mathrm{mM}$ in $68 \mathrm{mM}$ sodium citrate) was mixed with $0.2 \mathrm{~mL}$ of kluyveromyces delphensis yeast cell suspension diluted to reach an optical density $600 \mathrm{~nm} 0.4$ to 0.8 . The mixture was shaken and taken onto slide specimen to be counted after five minutes of incubation. The numbers of stained with methylene blue was dead cell (inactive) and the one that was unstained was live cell (active). The ratio of viable cell was the numbers of live cell divided by the total numbers of cells.

\subsection{Analyzed FT-IR for Ethanol Produced from Cheese Whey}

Alcohols have characteristic IR absorptions associated with the $\mathrm{O}-\mathrm{H}, \mathrm{C}-\mathrm{O}$ and the $\mathrm{C}-\mathrm{H}$ stretching vibrations. When the region $(3450 \mathrm{~cm}-1)$ run as a liquid film with a very intense and broad band indicated the $\mathrm{O}-\mathrm{H}$ stretch of alcohols, while the region $\left(1640 \mathrm{~cm}^{-1}\right)$ confirms the $\mathrm{C}-\mathrm{O}$ stretch. The bands at around $2060 \mathrm{~cm}-1$ and $665 \mathrm{~m}^{-1}$ were assigned as the symmetric stretching modes of the $-\mathrm{CH}_{2}$ and $-\mathrm{CH}_{3}$ groups, respectively. This ascertains that the product obtained from cheese whey is definitely ethanol due to the confirmation of these regions.

Table 1. Literature review comparison for ethanol yield from different source.

\begin{tabular}{|c|c|c|c|c|}
\hline No & References & Sources & Conclusions & Comparison \\
\hline 1 & [23] & Glucose & $\begin{array}{l}\text { Maximum ethanol produced is } 48.7 \mathrm{~g} / \mathrm{L} \text { from } 120 \mathrm{~g} / \mathrm{L} \text { of glucose by SK- } 4 \text { at } 10^{\circ} \mathrm{C} \text { and } 19 \text { days } \\
\text { fermentation }\end{array}$ & $40.6 \%$ \\
\hline 2 & [21] & $\begin{array}{l}\text { Sucrose (sugar } \\
\text { cane juice) }\end{array}$ & $\begin{array}{l}29 \mathrm{~g} / \mathrm{L} \text { ethanol is produced from sugar cane by Z.mobilis without initial ethanol or control } \\
\text { medium }\end{array}$ & $42 \%$ \\
\hline 3 & [This study] & Lactose (whey) & Maximum ethanol produced is $40.4 \%$ or $2.5 \mathrm{~g} / \mathrm{L}$ from $6.15 \mathrm{~g} / \mathrm{L}$ of Lactose by $K$. delphensis & $40.4 \%$ \\
\hline
\end{tabular}




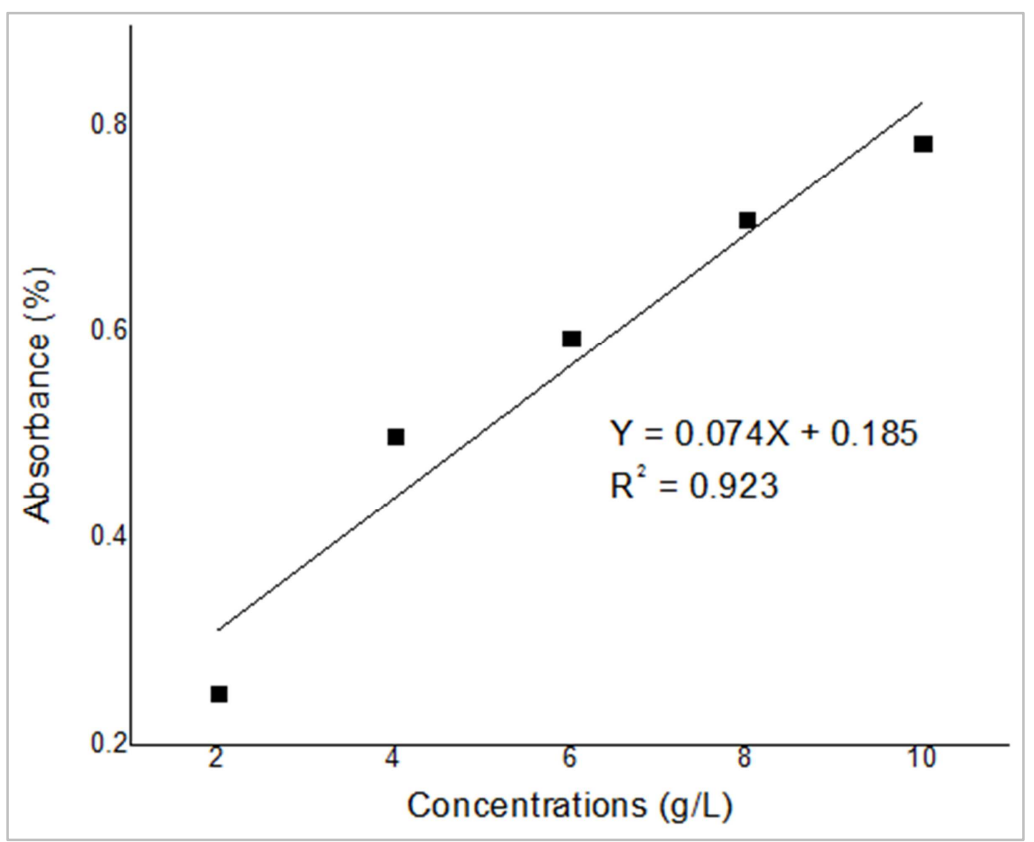

Figure 3. Graph of Concentration of Lactose (in gram per liter) Vs Its Absorbance (in\%).

The concentration of total reducing sugar in the hydrolyzed whey was obtained from the calibration plot in the above and expressed in $\mathrm{gm} / \mathrm{ml}$ in table above. The maximum reducing sugar was $7.8 \mathrm{~g} / \mathrm{L}$ determined by calibration curve.

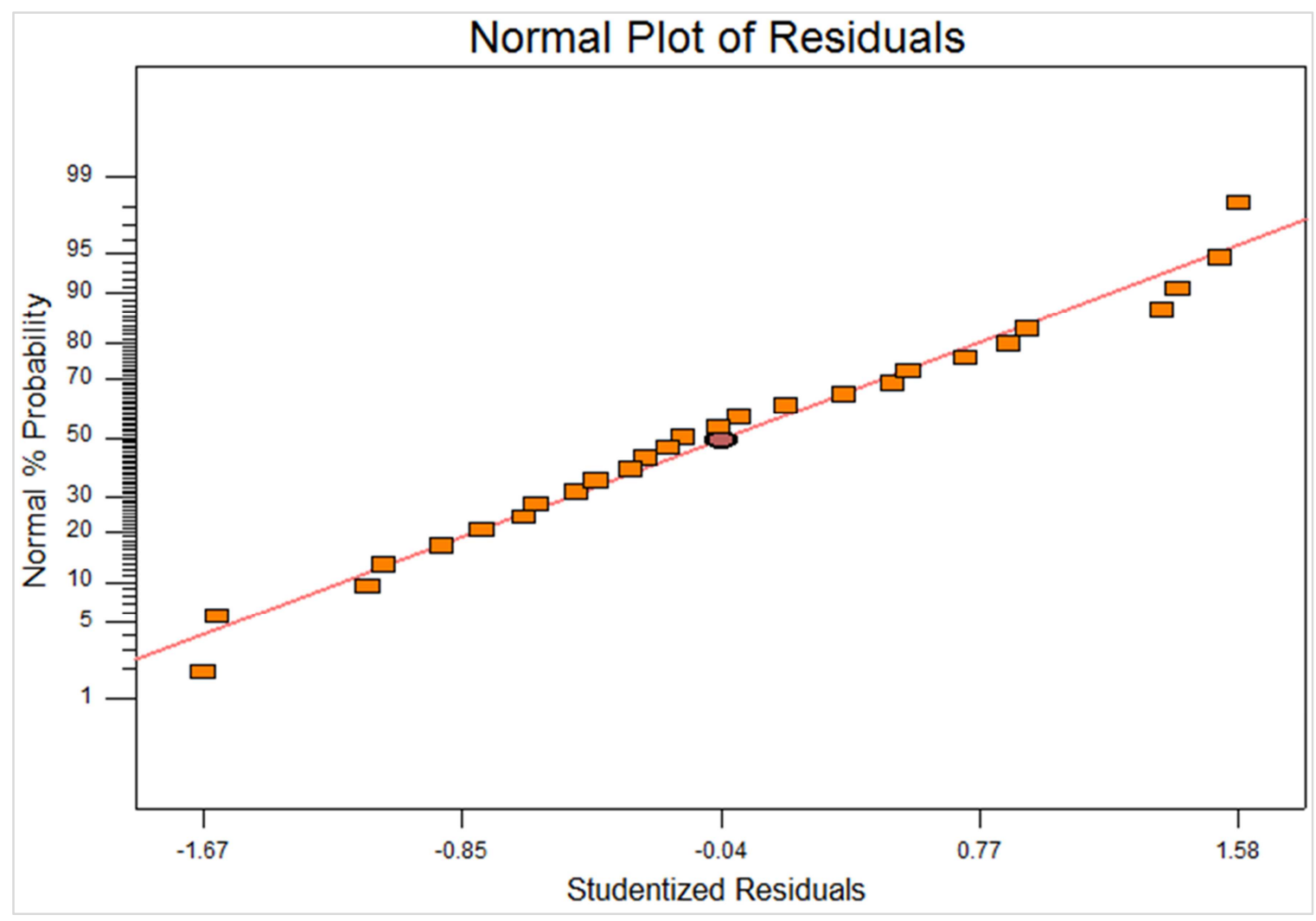

Figure 4. Normal Plots of Residuals.

The above plot of residuals implies the normal probability plot. In this experiment, the experimental data points in plots fit the straight line equation. As a result, the quadratic polynomial model satisfies the assumption of analysis of variance (ANOVA) which means the distribution of error was approximately normal. 


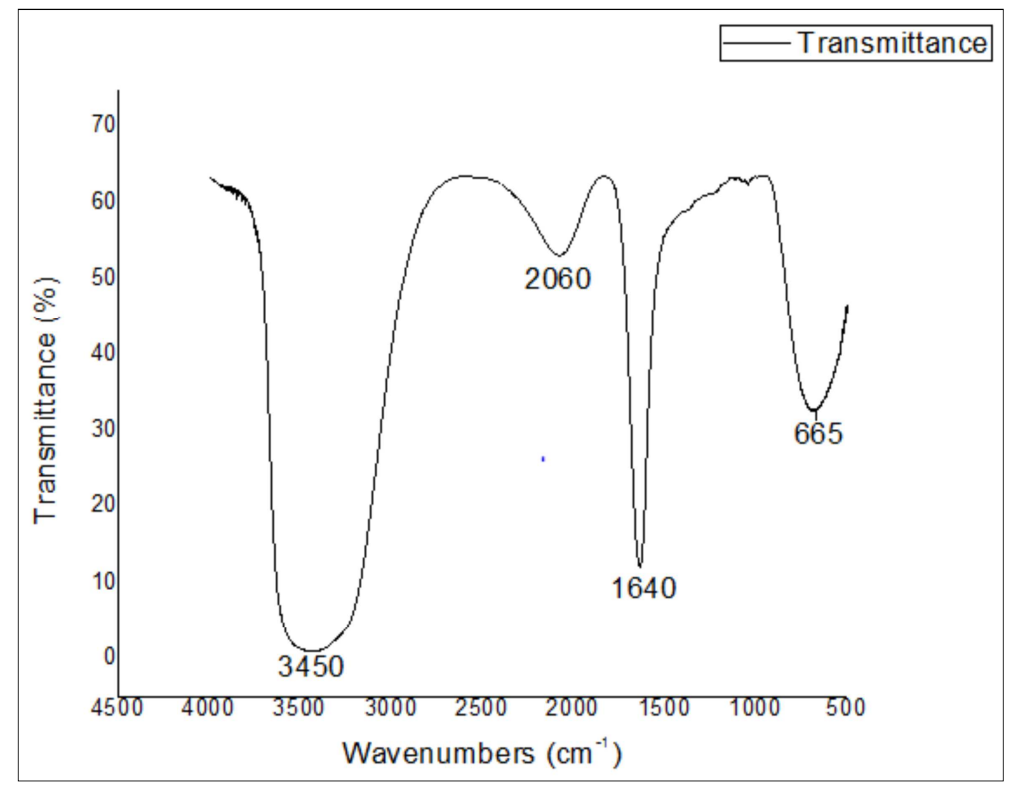

Figure 5. FTIR Analysis Graph.

In the above Table 1, Ethanol can be produced from different sugar source and the maximum yield obtained is almost close. This shows that dairy whey is comparatively a good source of sugar for the fermentation of ethanol by using different microorganism.

\section{Conclusions}

Dairy cheese whey was a byproduct that containing lactose (0. $36-0.48 \mathrm{~g} / \mathrm{mL})$ which can be fermented into ethanol. Consequently, cheese whey from dairy industry is concentrated at $105^{\circ} \mathrm{C}$ and hydrolyzed at $140^{\circ} \mathrm{C}$ to increase amount of lactose by enhancing its solubility. The kluyveromyces delphensis was used to ferment lactose into ethanol. The individual and interaction effects were studied by experimental design expert@6.0.8 version. As the result, optimization of ethanol through Response Surface Methodology was achieved at $6.15 \mathrm{~g} / \mathrm{L}$ lactose, $10 \mathrm{~g} / \mathrm{L}$ yeast cell, $27^{\circ} \mathrm{C}$ temperature and $5.5 \mathrm{pH}$ value. The functional groups of ethanol were analyzed by Fourier Transmission Infrared and its general properties were also analyzed. At the optimum conditions, maximum ethanol was produced and high ethanol yield was $40.4 \%$ in terms of significant factors. Consequently, desirability was checked from experimental design and thereby, the obtained desirability was 0.99 . It means that the values of significant factors selected for the optimization had no effect on ethanol yield. Therefore, cheese whey is a good resource for production of ethanol.

\section{Recommendations}

Based on the contemporary investigation the subsequent recommendations are advanced.

Supplementary researches have to be applied to increase the yield of ethanol from diary cheese whey using other microorganisms (in single or combined form) which have ability to ferment disaccharide and monosaccharide sugars of cheese whey into ethanol.

Optimization of fermentation process variables were investigated in this study. However, further optimization of concentration, hydrolysis and distillation are recommended to maximize the yield of ethanol from cheese whey.

Analysis of ethanol from cheese whey was investigated by FTIR and Density meter. Although further analysis by HPLC and GCMS are recommended to identify desired and undesired (side) products.

\section{Acknowledgements}

Above all, I would like to honor and give glory to God. My almighty lord and savior who has been my strength throughout studies and in the project work too. My heartfelt thank goes to my project advisor Dr. Eng. Hundessa Dessalegn Demshash, for his invaluable advice and diligent follow up of my progress. The reality is that he was much more than an advisor to me. I have learned a great deal from him during the advising time.

\section{References}

[1] Agustriyanto, R., \& Fatmawati, A. (2009). Model of Continuous Cheese Whey Fermentation by Candida Pseudotropicalis. Growth (Lakeland), 213-217.

[2] Almeida, B. (2011). Optimal fermentation conditions for maximizing the ethanol production by Kluyveromyces fragilis from cheese whey powder, 5, 5-10. https://doi.org/10.1016/j.biombioe.2011.01.045.

[3] Alsaed, A. K., Ahmad, R., Aldoomy, H., El-Qader, S. A., Saleh, D., Sakejha, H., \& Mustafa, L. (2013). Characterization, concentration and utilization of sweet and acid whey. Pakistan Journal of Nutrition, 12 (2), 172-177. https://doi.org/10.3923/pjn.2013.172.177. 
[4] Božanić, R., Barukčić, I., \& Lisak, K. (2014). Possibilities of whey utilisation. Journal of Nutrition and Food Sciences, 2 (7), 1-7.

[5] By, R. (2018). The Effect of Temperature on the Metabolism of Baker $\hat{a} €^{\mathrm{TM}} \mathrm{s}$ Yeast growing on Continuous Culture, (May), 107-116.

[6] Chandra, R., Castillo-zacarias, C., Delgado, P., \& Parrasaldívar, R. (2018). A biore fi nery approach for dairy wastewater treatment and product recovery towards establishing a biore fi nery complexity index. Journal of Cleaner Production, 183, 1184-1196. https://doi.org/10.1016/j.jclepro.2018.02.124.

[7] Diniz, R. H. S., Rodrigues, M. Q. R. B., Fietto, L. G., Passos, F. M. L., \& Silveira, W. B. (2014). Optimizing and validating the production of ethanol from cheese whey permeate by Kluyveromyces marxianus UFV-3. Biocatalysis and Agricultural Biotechnology, 3 (2), 111-117. https://doi.org/10.1016/j.bcab.2013.09.002.

[8] Fombad, R. (2011). A Review of the Ethiopian Dairy Sector Edited by Rudolf Fombad. FAO Sub Regional Office for Eastern Africa (FAO/SFE).

[9] Gebreyohannes, Y. (2013). Long-term Bioethanol Shift and Transport Fuel Substitution in Ethiopia. Stockholm Environment Institute, Master Thesis. https://doi.org/(unpublished).

[10] Ghaly, A. E., Mahmoud, N. S., Rushton, D. G., \& Arab, F. (2007). Potential environmental and health impacts of high land application of cheese whey. American Journal of Agricultural and Biological Sciences, 2 (2), 106-117. https://doi.org/10.3844/ajabssp.2007.

[11] Ghanadzadeh, H., \& Ghorbanpour, M. (2012). Optimization of Ethanol Production from Cheese Whey Fermentation in a Batch-Airlift Bioreactor. J Bioengineer \& Biomedical ..., 2 (2), 111. https://doi.org/10.4172/2155-9538.1000111106.117.

[12] Hamilton, R. (2011). The manufacture of ethanol from whey. Yeast, 1-7.

[13] Johansson, T. (2008). Local Production and Use of bio-ethanol for Transport in Ethiopia Status, challenges and lessons Getish Tekle. Environmental Management, (September).

[14] Ling, C. (2008). Whey to Ethanol: A Biofuel Role for Dairy Cooperatives? USDA Rural Development, 1-19. Retrieved from http://www.rd.usda.gov/files/RR214.pdf.

[15] Macwan, S. R., Dabhi, B. K., Parmar, S. C., \& Aparnathi, K. D. (2016). Whey and its Utilization. International Journal of Current Microbiology and Applied Sciences, 5 (8), 134-155. https://doi.org/10.20546/ijcmas.2016.508.016.

[16] Parashar, A., Jin, Y., Mason, B., Chae, M., \& Bressler, D. C. (2016). Incorporation of whey permeate, a dairy effluent, in ethanol fermentation to provide a zero waste solution for the dairy industry. Journal of Dairy Science, 99 (3), 1859-1867. https://doi.org/10.3168/jds.2015-10059.
[17] Pasotti, L., Zucca, S., Casanova, M., Micoli, G., Cusella De Angelis, M. G., \& Magni, P. (2017). Fermentation of lactose to ethanol in cheese whey permeate and concentrated permeate by engineered Escherichia coli. BMC Biotechnology, 17 (1), 48. https://doi.org/10.1186/s12896-017-0369-y.

[18] Prazeres, A. R., Carvalho, F., \& Rivas, J. (2012). Cheese whey management : A review. Journal of Environmental Management, 110, 48-68. https://doi.org/10.1016/j.jenvman.2012.05.018.

[19] Shapouri, H., \& Salassi, M. (2006). The economic feasibility of ethanol production from sugar in the United States. USDA Report, (July), 78. https://doi.org/10.1016/j.biortech.2007.11.013

[20] Shrestha, S., Shrestha, F., Rajbhandari, P., Baral, R., \& Krishna, S. (2012). Enhanced Production of Ethanol from Cheese whey by Agarose and Alginate immobilization of Yeast Cells, 30, 159-164.

[21] Tano, Marcia Sadae, and João Batista Buzato. 2003. "Effect of the Presence of Initial Ethanol on Ethanol Production in Sugar Cane Juice Fermented by Zymomonas Mobilis." Brazilian Journal of Microbiology 34 (3): 242-44. https://doi.org/10.1590/S1517-83822003000300012.

[22] Tsakali, E., Petrotos, K., \& Allessandro, A. D. (2010). A review on whey composition and the methods used for its utilization for food and pharmaceutical products. 6th International Conference on Simulation and Modelling in the Food and Bio-Industry. FOODSIM, 8.

[23] Tsuji, Masaharu, Shiv M. Singh, Yuji Yokota, Sakae Kudoh, and Tamotsu Hoshino. 2013. "Influence of Initial pH on Ethanol Production by the Antarctic Basidiomycetous Yeast Mrakia Blollopis." Bioscience, Biotechnology and $\begin{array}{llll}\text { Biochemistry } & 77 & \text { (12): }\end{array}$ https://doi.org/10.1271/bbb.130497.

[24] Zohri, A. A., Gomah, N. H., \& Ali, M. A. (2014). Utilization of Cheese Whey for Bio-ethanol Production, 2 (4), 57-69. https://doi.org/10.13189/ujmr.2014.020401.

\section{Biography}

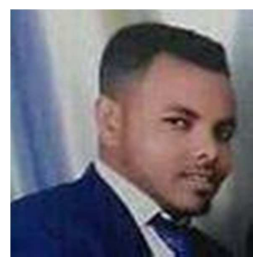

Wubshet Alemu Woldie was born on September 12, 1991 at Colle, Oromia, Ethiopia. I was graduated from Addis Ababa university, [Facality: Addis Ababa Institute of Technology] with B.Sc. Degree in Chemical Engineering (Process Engineering Stream) and M.Sc. in Chemical Engineering (Environmental Engineering Stream). I am currently working at the position of Senior Lecturer and Researcher in Debra Berhan University, Ethiopia. 